\title{
ANALISIS KUALITAS INSTRUMEN UNTUK MENGUKUR KEMAMPUAN PEMECAHAN MASALAH SISWA SELAMA PEMBELAJARAN DARING DI MASA PANDEMI
}

\author{
Rizky Ananda Setiyawan ${ }^{1}$, Palupi Sri Wijayanti ${ }^{2}$ \\ 1,2 Pendidikan Matematika, Fakultas Keguruan dan Ilmu Pendidikan, Universitas PGRI Yogyakarta \\ rizkyananda24@gmail.com ${ }^{1}$, palupi@upy.ac.id ${ }^{2}$
}

\begin{abstract}
The instruments used in evaluating mathematics at school during the pandemic period must be tested for quality. The purpose of this research was to determine the quality of the problem solving ability test instruments used in online learning during the Covid-19 pandemic based on the level of validity, reliability, differentiation, level of difficulty and contributing to education regarding good quality mathematics problem solving ability test instruments. This research is quantitative descriptive research conducted at SMP N 3 Jetis through three phases of activity, namely preparation, implementation, and end. Quantitative Data obtained is a score of mathematical problem-solving skills. The data analysis technique used is quantitative to determine the level of instrument quality in empirical data while qualitative to decide on the category of validity, reliability, different power, and difficulty level of test instruments. The results showed that quality analysis of test instruments, the ability to solve mathematics problem $100 \%$ valid, reliability of 0.858 with good category, differentiation power included in the level is enough. In contrast, the difficulty level of test instruments consists of 3 rounds of medium type and 1 item of the easy category.
\end{abstract}

Keywords: instrument test, quality analysis, problem-solving, pandemic, covid-19

\begin{abstract}
Abstrak
Instrumen yang digunakan dalam mengevaluasi pembelajaran matematika di sekolah selama masa pandemi harus teruji kualitasnya. Tujuan penelitian ini untuk mengetahui kualitas instrumen tes kemampuan pemecahan masalah yang digunakan dalam pembelajaran daring selama masa pandemi covid-19 berdasarkan tingkat validitas, reliabilitas, daya pembeda, tingkat kesukaran dan memberikan kontribusi terhadap pendidikan mengenai instrumen tes kemampuan pemecahan masalah matematika yang berkualitas baik. Penelitian ini merupakan penelitian deskriptif kuantitatif yang dilakukan di SMP N 3 Jetis melalui tiga tahapan kegiatan yaitu persiapan, pelaksanaan dan akhir. Data kuantitatif yang diperoleh adalah skor kemampuan pemecahan masalah matematika. Teknik analisis data yang digunakan yaitu kuantitatif untuk menentukan tingkat kualitas instrumen secara data empiris sedangkan kualitatif untuk menentukan kategori tingkat validitas, reliabilitas, daya beda dan tingkat kesukaran instrumen tes. Hasil penelitian menunjukkan bahwa analisis kualitas instrumen tes kemampuan pemecahan masalah matematika $100 \%$ valid, reliabilitas sebesar 0,858 dengan kategori baik, daya pembeda termasuk dalam kategori cukup, sedangkan tingkat kesukaran instrumen tes terdiri dari 3 butir soal kategori sedang dan 1 butir soal kategori mudah.
\end{abstract}

Kata kunci: uji instrumen, analisis kualitas, pemecahan masalah, pandemi, covid-19 


\section{PENDAHULUAN}

Evaluasi pembelajaran merupakan suatu proses untuk mendapatkan, menyajikan suatu informasi yang bermanfaat untuk pengambilan keputusan dalam proses pembelajaran yang akan berguna untuk pembelajaran selanjutnya. Dalam Undang-undang Nomor 20 Tahun 2003 pasal 57 ayat 1 tentang Sistem Pendidikan Nasional dijelaskan evaluasi dilakukan dalam rangka pengendalian mutu pendidikan secara nasional sebagai bentuk akuntabilitas penyelenggara pendidikan kepada pihakpihak yang berkepentingan.

Bentuk evaluasi pembelajaran salah satunya adalah tes. Tes merupakan alat ukur untuk mengukur pengetahuan, keterampilan siswa dalam menyelesaikan suatu masalah. Penyusunan instumen tes harus memenuhi standar agar dapat dijadikan sebagai tolak ukur kemampuan siswa. Standar evaluasi yang dikatakan berkualitas baik berupa instrumen tes yang paling tidak memenuhi syarat valid dan reliabel, disamping itu juga harus memperhatikan daya pembeda dan tingkat kesukaran (Iskandar \& Rizal, 2017).

Untuk menciptakan instrumen tes yang baik dan benar guna memperbaiki kualitas pembelajaran maka diperlukan analisis instrumen tes. Perlu diketahui bahwa analisis kualitas instrumen tes bisa dilakukan dengan mencari validitas, reliabilitas, tingkat kesukaran dan daya pembeda. Analisis kualitas instrumen tes adalah tahapan yang harus dilalui oleh seseorang dengan maksud untuk mengetahui derajat kualitas suatu instrumen tes secara tiap butir soal yang menjadi bagian suatu instrumen tes tersebut maupun secara keseluruhan.

Sesuai Permendikbud Nomor 58 tahun 2014 terdapat tujuan mempelajari pelajaran matematika adalah siswa mampu mempunyai kemampuan memecahkan masalah matematika berupa kemampuan memahami suatu masalah, menyusun model matematika, menerapkan strategi untuk menyelesaikan masalah dan menginterpretasi solusi yang diperoleh. Menurut (A. Susanto, 2013) pemecahan masalah (problem solving) merupakan bagian yang penting dalam matematika. Pemecahan masalah merupakan suatu proses mengimplementasikan pengetahuan (knowledge) atau pengalaman yang pernah dialami atau diperoleh seseorang sebelumnya ke dalam situasi yang baru. Pemecahan masalah juga merupakan aktivitas yang perlu ditekankan dalam belajar matematika karena tujuan yang hendak dicapai berkaitan dengan kehidupan sehari-hari.

Aktifitas keseharian akan membentuk suatu kebiasaan yang menunjukan budaya dari sekelompok masyarakat (Supriyanti, 2020) dan Masalah adalah suatu keadaan yang belum diketahui solusinya atau strategi dalam mencari solusi tersebut. Pemecahan masalah adalah pusat belajar dan mengajarkan matematika (Wijayanti, 2013). Sedangkan menurut (Uno \& Koni, 2016) pemecahan masalah adalah kemampuan yang dimiliki peserta didik untuk memahami masalah, memilih 
pendekatan dan strategi pemecahan masalah dan menyelesaikan model untuk menjawab masalah.

Indikator pemecahan masalah matematis antara lain: a) Menunjukan pemahaman suatu masalah; b) Mampu membuat atau menyusun model matematika, meliputi merumuskan masalah situasi seharihari dalam matematika; c) Memilih dan mengembangkan strategi pemecahan masalah, meliputi memunculkan alternatif cara penyelesaian; d) Mampu menjelaskan dan memeriksa kebenaran jawaban yang diperoleh (Ruswati, 2018).

Pada kondisi pandemi covid-19 pembelajaran secara daring merupakan salah satu alternatif pembelajaran yang harus dilakukan guna melanjutkan pendidikan. Melalui pembelajaran daring siswa dituntut untuk fokus pada layar gawai dalam menyelesaikan tugas yang diberikan oleh guru. Pembelajaran daring adalah pembelajaran dengan memanfaatkan jaringan internet dalam proses pembelajaran. Melalui pembelajaran seseorang memiliki keleluasan waktu dalam belajar (Isman, 2013). Pendapat serupa dijelaskan oleh (Elianur, 2020) bahwa pembelajaran daring adalah pembelajaran yang memanfaatkan sarana internet sebagai belajar oleh penggunanya. Dalam prakteknya media pembelajaran secara daring bisa memanfaatkan aplikasi pada handphone atau website.

Selanjutnya akan dibahas mengenai validitas, reliabilitas, daya pembeda, dan tingkat kesukaran. Validitas merupakan derajat ketepatan antara data yang terjadi pada obyek penelitian dengan data yang dapat dilaporkan oleh peneliti (Sugiyono, 2015). Sebuah tes dikatakan memiliki validitas jika hasilnya sesuai dengan kriteria, dalam artian memiliki kesejajaran antara hasil tes dengan kriteria (Arikunto, 2018). Sebuah tes dikatakan valid apabila tes tersebut dapat dengan tepat mengukur apa yang seharusnya diukur (Solichin, 2017)

Kata reliabilitas dalam bahasa inggris yaitu reliabillity, kata asal reliable memiliki arti dapat dipercaya. Tes disebut dapat dipercaya apabila tes tersebut diteskan berkali-kali memberikan hasil yang tetap. Sebuah tes disebut memiliki reliabilitas apabila hasil tes tersebut menunjukkan ketetapan (Arikunto, 2018). Reliabilitas suatu instrumen tes adalah keajegan atau kekonsistenan instrumen tes tersebut apabila diberikan kepada subyek yang sama meskipun oleh orang yang berbeda, waktu yang berbeda, atau tempat yang berbeda maka akan memberikan hasil yang tidak jauh berbeda (Lestari \& Yudhanegara, 2017).

Daya pembeda suatu butir soal adalah kemampuan butir soal dalam membedakan antara siswa yang dapat menjawab soal dengan tepat dan siswa yang menjawab soal kurang tepat (Lestari \& Yudhanegara, 2017). Daya pembeda suatu soal adalah kemampuan soal dalam hal membedakan antara siswa yang berkemampuan tinggi dengan siswa yang berkemampuan rendah (Arikunto, 2018). Analisis daya beda memiliki makna mengkaji suatu butir soal dari segi kesanggupan tes tersebut dalam membedakan siswa yang memiliki kategori rendah dan kategori tinggi. Daya pembeda butir soal adalah kemampuan suatu butir tes untuk dapat membedakan antara testee yang berkemampuan 
tinggi dan berkemampuan rendah (H. Susanto et al., 2015).

Tingkat kesukaran adalah derajat kesukaran suatu butir soal yang dinyatakan dalam bentuk suatu bilangan (Lestari \& Yudhanegara, 2017). Soal disebut baik apabila soal tersebut tidak termasuk dalam kategori terlalu mudah atau terlalu sukar. Soal terlalu sukar akan membuat siswa menjadi putus asa dan patah semangat karena di luar kemampuannya, sedangkan soal terlalu mudah tidak dapat merangsang siswa untuk mempertinggi usaha memecahkannya (Arikunto, 2018). Tingkat kesukaran menyatakan sejauh mana soal tersebut mudah dan sulit bagi siswa. Semakin besar persentase siswa menjawab soal dengan benar maka semakin mudah soal, sebaliknya semakin kecil persentase siswa menjawab soal dengan benar maka semakin sulit soal (Hanifah, 2014).

\section{METODE PENELITIAN}

Penelitian ini termasuk dalam kategori penelitian deskriptif kuantitatif. Penelitian deskriptif adalah penelitian yang menggambarkan lebih detail mengenai suatu gejala berdasarkan data yang ada, menyajikan data, menganalisis dan menginterpretasi. Data kuantitatif diperoleh dari hasil instrumen tes kemampuan pemecahan masalah matematika siswa. Subjek penelitian ini adalah siswa kelas VII C SMP Negeri 3 Jetis tahun ajaran 2019/2020. Sampel dipilih menggunakan teknik purposive sample. Instrumen pengumpulan data berupa tes kemampuan pemecahan masalah matematika siswa dan dokumentasi. Analisis data dalam penelitian ini adalah analisis data kuantitatif berupa uji validitas, reliabilitas, daya pembeda, dan tingkat kesukaran. Perhitungan validitas, reliabilitas, daya pembeda dan tingkat kesukaran menggunakan bantuan program SPSS 20. dan Microsoft Excel.

\section{HASIL DAN PEMBAHASAN}

\section{Hasil Penelitian}

Kualitas instrumen berdasarkan validitas, reliabilitas, daya beda dan tingkat kesukaran diperoleh hasil sebagai berikut:

a. Validitas

Validitas dihitung dengan menggunakan rumus korelasi product momen Pearson. Jumlah siswa yang mengerjakan instrumen tes ini sebanyak 22 siswa, sehingga diketahui $\mathrm{n}=22$ dan nilai $r$ tabel menunjukkan angka 0,424. Berdasarkan analisis dapat diketahui bahwa dari 4 butir soal yang diujikan, keempat butir soal tersebut masuk dalam kategori valid. Adapun distribusinya sebagai berikut:

Tabel 1. Hasil Perhitungan Validitas

\begin{tabular}{ccccc}
\hline No Soal & $\mathrm{r}$ hitung & $\mathrm{r}$ tabel & Kategori & Interpretasi \\
\hline 1 & 0,883 & 0,424 & Valid & Baik \\
\hline \multicolumn{5}{c}{133} \\
\end{tabular}




\begin{tabular}{ccccc}
\hline 2 & 0,913 & 0,424 & Valid & Sangat baik \\
3 & 0,859 & 0,424 & Valid & Baik \\
4 & 0,684 & 0,424 & Valid & Cukup baik \\
\hline
\end{tabular}

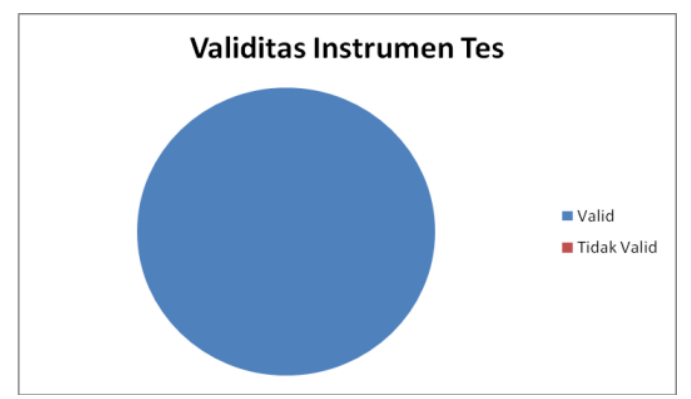

Gambar 1. Gambar Diagram Pie Analisis Validitas Instrumen Tes

\section{b. Reliabilitas}

Hasil analisis reliabilitas menggunakan bantuan program SPSS 20. diperoleh hasil sebagai berikut:

Tabel 2. Hasil Perhitungan Reliabilitas

\begin{tabular}{rr}
\hline $\begin{array}{c}\text { Cronbach's } \\
\text { Alpha }\end{array}$ & N of Items \\
\hline, 858 & 4 \\
\hline
\end{tabular}

Diketahui bahwa instrumen tes kemampuan pemecahan masalah matematika ini termasuk reliabel dan untuk nilai reliabilitasnya sebesar 0,858 dengan kategori baik.

c. Daya Pembeda

Analisis daya pembeda dihitung menggunakan bantuan Microsoft Excel diperoleh hasil sebagai berikut:

Tabel 3. Hasil Perhitungan Daya Pembeda

\begin{tabular}{ccc}
\hline No Soal & Daya Pembeda & Interpretasi \\
\hline 1 & 0,393 & Cukup \\
2 & 0,383 & Cukup \\
3 & 0,313 & Cukup \\
4 & 0,282 & Cukup \\
\hline
\end{tabular}




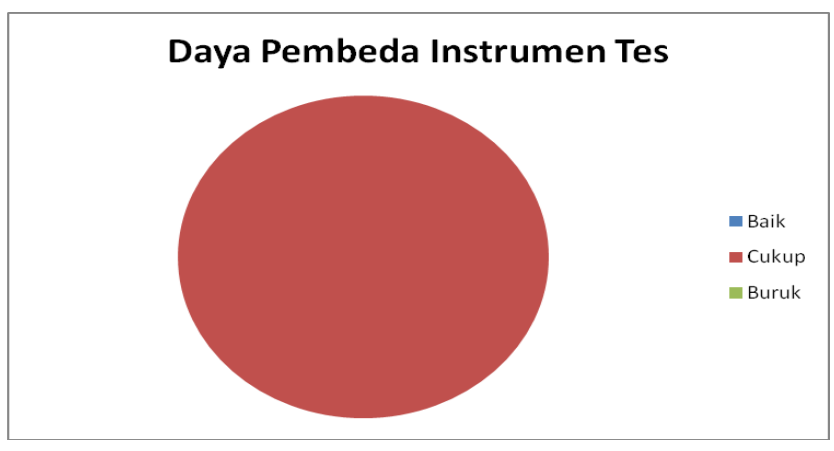

Gambar 2. Gambar Diagram Pie Analisis Daya Pembeda

\section{d. Tingkat Kesukaran}

Analisis tingkat kesukaran dengan menggunakan Microsoft Excel diperoleh hasil sebagai berikut:

Tabel 4. Hasil Perhitungan Tingkat Kesukaran

\begin{tabular}{ccc}
\hline No Soal & $\begin{array}{c}\text { Tingkat } \\
\text { Kesukaran }\end{array}$ & Interpretasi \\
\hline 1 & 0,429 & Sedang \\
2 & 0,434 & Sedang \\
3 & 0,560 & Sedang \\
4 & 0,787 & Mudah \\
\hline
\end{tabular}

Pembahasan

Penelitian ini menghasilkan instrumen tes kemampuan pemecahan masalah matematika kelas VII. Instrumen tes ini dirancang untuk mengetahui kualitas instrumen tes yang dibuat oleh peneliti yang nantinya bisa dijadikan referensi di dunia pendidikan khususnya matematika, karena instrumen ini sudah melalui pengujian selain itu instrumen ini sekiranya mampu menjadi solusi dalam mengatasi permasalahan kualitas instrumen yang di masa pandemi covid-19 ini jarang sekali guru melakukan uji kualitas instrumen dengan alasan berbagai hal. Instrumen tes akan menjadi bias apabila tidak melalui pengujian, bisa saja instrumen tidak dapat mengukur kemampuan siswa.

Ada beberapa indikator kualitas instrumen tes dapat dikatakan berhasil apabila secara empiris instrumen tersebut memiliki validitas $r$ hitung $>r$ tabel, jika reliabilitas tes $0,40<r_{11}<1,00$, jika tingkat kesukaran merata (Riyani et al., 2017). Sedangkan untuk daya pembeda butir soal yang digunakan jika indeks daya beda bernilai negatif, indeks daya pembeda sendiri memiliki rentang $-1,0$ sampai dengan $+1,0$. Daya pembeda negatif menunjukkan siswa yang termasuk dalam kelompok bawah lebih banyak menjawab soal dengan benar daripada kelompok atas, sehingga butir tes harus digugurkan atau direvisi jika tidak dapat membedakan kemampuan siswa (Rusmayani, 2019).

Pada penelitian ini menunjukkan kualitas instrumen tes dari 4 butir soal $r$ hitung $>\mathrm{r}$ tabel, reliabilitas sebesar 0,858 sehingga termasuk reliabel, daya pembeda soal tidak ada yang bernilai negatif, sedangkan tingkat kesukaran soal perlu ditambahkan butir soal kategori sukar karena pada instrumen peneliti hanya memuat butir soal kategori mudah dan sedang. Untuk lebih jelasnya dipaparkan oleh 
Jurnal Lebesgue : Jurnal Ilmiah Pendidikan Matematika, Matematika dan Statistika

Rizky Ananda Setiyawan, Palupi Sri Wijayanti

Volume 1, No. 2, Agustus 2020 hal.130-139

DOI Artikel : 10.46306/lb.v1i2.26

peneliti sebagai berikut:

a. Validitas

Pembahasan validitas instrumen tes kemampuan pemecahan masalah matematika sebagai berikut:

1) Hasil penelitian soal nomor 1 menunjukkan validitas sebesar 0,883 sehingga dalam kriteria baik, respon siswa secara online melalui google form juga menunjukkan bahwa soal ini dapat mengukur kemampuan pemecahan masalah matematika sebesar 79,3\% dan siswa mengaku belum pernah menemui jenis soal sejenis ini sebelumnya sebesar $56,7 \%$.

2) Hasil penelitian soal nomor 2 menunjukkan validitas sebesar 0,913 sehingga dalam kriteria sangat baik, respon siswa secara online melalui google form juga menunjukkan bahwa soal ini dapat mengukur kemampuan pemecahan masalah matematika sebesar 82,8\% dan siswa mengaku belum pernah menemui jenis soal sejenis ini sebelumnya sebesar 65,5\%.

3) Hasil penelitian soal nomor 3 menunjukkan validitas sebesar 0,859 sehingga dalam kriteria baik, respon siswa secara online melalui google form juga menunjukkan bahwa soal ini dapat mengukur kemampuan pemecahan masalah matematika sebesar 75,9\% dan siswa mengaku belum pernah menemui jenis soal sejenis ini sebelumnya sebesar $58,6 \%$.

4) Hasil penelitian soal nomor 4 menunjukkan validitas sebesar 0,684 sehingga dalam kriteria cukup baik, respon siswa secara online melalui google form juga menunjukkan bahwa soal ini cukup mengukur kemampuan pemecahan masalah matematika sebesar 58,6,\% dan siswa menjawab pernah menemui jenis soal yang hampir sama sebesar 37,9\%.

Dalam hal ini, berarti instrumen ini dapat digunakan kembali untuk tes yang akan datang. Soal dapat menjadi valid karena konstruksinya baik dan mencakup materi yang benar-benar mencakup keseluruhan yang akan diukur.

\section{b. Reliabilitas}

Hasil analisis instrumen tes menggunakan bantuan program SPSS 20. diketahui bahwa reliabilitas instrumen tes kemampuan pemecahan masalah matematika sebesar 0,858 dengan kategori baik. Dapat dikatakan instrumen ini mempunyai kekonsistenan, apabila diberikan kepada subyek yang sama meskipun oleh orang yang berbeda, waktu yang berbeda, atau tempat yang berbeda maka akan memberikan hasil yang relatif sama.

c. Daya Pembeda

Pembahasan daya pembeda instrumen tes kemampuan pemecahan masalah matematika sebagai berikut:

1) Hasil penelitian soal nomor 1 menunjukkan daya pembeda sebesar 0,393 sehingga dalam kriteria cukup baik, sebagian besar responden menyatakan bahwa soal ini sedang dan data menunjukkan bahwa skor siswa cukup bervariasi dalam kelompok atas dan kelompok bawah 
sehingga soal ini cukup baik dalam membedakan siswa yang berkemampuan tinggi dan berkemampuan rendah.

2) Hasil penelitian soal nomor 2 menunjukkan daya pembeda sebesar 0,383 sehingga dalam kriteria cukup baik, sebagian besar responden menyatakan bahwa soal ini sedang dan data menunjukkan bahwa skor siswa cukup bervariasi dalam kelompok atas dan kelompok bawah sehingga soal ini cukup baik dalam membedakan siswa yang berkemampuan tinggi dan berkemampuan rendah.

3) Hasil penelitian soal nomor 3 menunjukkan daya pembeda sebesar 0,313 sehingga dalam kriteria cukup baik, sebagian besar responden menyatakan bahwa soal ini sedang dan data menunjukkan bahwa skor siswa cukup bervariasi dalam kelompok atas dan kelompok bawah sehingga soal ini cukup baik dalam membedakan siswa yang berkemampuan tinggi dan berkemampuan rendah.

4) Hasil penelitian soal nomor 4 menunjukkan daya pembeda sebesar 0,282 sehingga dalam kriteria cukup baik, sebagian besar responden menyatakan bahwa soal ini sedang dan data menunjukkan bahwa skor siswa cukup bervariasi dalam kelompok atas dan kelompok bawah sehingga soal ini cukup baik dalam membedakan siswa yang berkemampuan tinggi dan berkemampuan rendah.

\section{d. Tingkat Kesukaran}

Pembahasan tingkat kesukaran instrumen tes kemampuan pemecahan masalah matematika sebagai berikut:

1) Hasil penelitian soal nomor 1 menunjukkan tingkat kesukaran sebesar 0,429 sehingga dalam kriteria sedang, respon siswa secara online melalui google form juga menunjukkan bahwa siswa menganggap soal ini sedang sebesar $75,9 \%$ dan siswa memperoleh jawaban soal ini secara mandiri sebesar $72,4 \%$.

2) Hasil penelitian soal nomor 2 menunjukkan tingkat kesukaran sebesar 0,434 sehingga dalam kriteria sedang, respon siswa secara online melalui google form juga menunjukkan bahwa siswa menganggap soal ini sedang sebesar $69 \%$ dan siswa memperoleh jawaban soal ini secara mandiri sebesar 58,6\%.

3) Hasil penelitian soal nomor 3 menunjukkan tingkat kesukaran sebesar 0,560 sehingga dalam kriteria sedang, respon siswa secara online melalui google form juga menunjukkan bahwa siswa menganggap soal ini sedang sebesar $93,1 \%$ dan siswa memperoleh jawaban soal ini secara mandiri sebesar $72,4 \%$.

4) Hasil penelitian soal nomor 4 menunjukkan tingkat kesukaran sebesar 0,787 sehingga dalam kriteria mudah, respon siswa secara online melalui google form juga menunjukkan bahwa 
siswa menganggap soal ini mudah sebesar $10,3 \%$ dan diketahui siswa memperoleh jawaban soal ini mencontek teman $20,7 \%$ dan melalui internet $20,7 \%$.

\section{KESIMPULAN}

Setelah dilakukan analisis dan pembahasan diperoleh kesimpulan bahwa kualitas instrumen tes kemampuan pemecahan masalah matematika ini memenuhi $100 \%$ valid. Reliabilitas instrumen tes kemampuan pemecahan masalah matematika sebesar 0,858 dengan kategori baik. Daya pembeda terdiri dari 4 butir soal $100 \%$ kategori cukup. Tingkat kesukaran instrumen tes kemampuan pemecahan masalah matematika terdiri dari 3 butir soal kategori sedang dan 1 butir soal kategori mudah.

Dalam rangka menciptakan kualitas instrumen tes yang sesuai standar maka peneliti memberikan saran terhadap peneliti yang akan datang yaitu 1) Sebaiknya instrumen tes yang akan diberikan siswa harus melalui analisis kualitas instrumen tes guna menghindari bias dalam mengukur kemampuan siswa. 2) Sebaiknya dalam instrumen tes terdapat tingkat kesukaran yang bervariasi, yaitu mudah, sedang, dan sukar. Pada penelitian ini kurangnya butir soal berkategori sukar, yang nantinya bisa ditambahkan oleh peneliti yang akan datang. 3) Apabila menemui butir soal yang sudah berfungsi dengan baik bisa digunakan sebagai referensi tes yang akan datang, apabila menemui butir soal yang kurang berfungsi dengan baik sebaiknya diperbaiki atau dibuang.

\section{DAFTAR PUSTAKA}

Arikunto, S. (2018). Dasar-Dasar Evaluasi Pendidikan. Rineka Cipta.

Dela, R., Widia, U., \& Eka, S. (2018). Analisis Kesalahan Siswa SMP Dalam Menyelesaikan Soal Kemampuan Pemecahan Masalah Matematis Ditinjau Dari Tiga Aspek. Jurnal Maju, 5(1), 91-107.

Elianur, C. (2020). PILIHAN MEDIA PEMBELAJARAN DARING OLEH GURU PAI DI BENGKULU TENGAH. Jurnal As-Salam, 4(1), 37-45.

Hanifah, N. (2014). PERBANDINGAN TINGKAT KESUKARAN , DAYA PEMBEDA PELAJARAN EKONOMI. Jurnal Sosio E-KONS, 6(1), 41-55.

Iskandar, A., \& Muhammad, R. (2017). ANALISIS KUALITAS SOAL DI PERGURUAN TINGGI BERBASIS APLIKASI TAP. Jurnal Penelitiam Dan Evaluasi Pendidikan, 21(2), 12-23. Isman, M. (2013). PEMBELAJARAN MODA DALAM JARINGAN ( MODA DARING ). Jurnal Muhammadiyah Surakarta, 586-588.

Lestari, K., \& Yudhanegara, M. (2017). Penelitian Pendidikan Matematika. Refika Aditama. Riyani, R., Maizora, S., \& Hanifah, H. (2017). Uji Validitas Pengembangan Tes Untuk Mengukur Kemampuan Pemahaman Relasional Pada Materi Persamaan Kuadrat Siswa Kelas VIII SMP. Jurnal 
Jurnal Lebesgue : Jurnal Ilmiah Pendidikan Matematika, Matematika dan Statistika

Rizky Ananda Setiyawan, Palupi Sri Wijayanti

Volume 1, No. 2, Agustus 2020 hal.130-139

DOI Artikel : 10.46306/lb.v1i2.26

Penelitian Pembelajaran Matematika Sekolah (JP2MS), 1(1), 60-65.

https://doi.org/10.33369/jp2ms.1.1.60-65

Rusmayani. (2019). ANALISIS BUTIR SOAL PENILAIAN AKHIR SEMESTER GENAP MATA

PELAJARAN PENDIDIKAN AGAMA ISLAM DI SMP BINTANG PERSADA TABANAN-BALI.

Widya Balina, 5(9), 1-8.

Solichin, M. (2017). ANALISIS DAYA BEDA SOAL, TARAF KESUKARAN, VALIDITAS BUTIR

TES, INTERPRETASI HASIL TES DAN VALIDITAS RAMALAN DALAM EVALUASI

PENDIDIKAN. Jurnal Manajemen \& Pendidikan Islam, 2(2), 192-213.

Sugiyono. (2015). Metode Penelitian Pendidikan Pendekatan Kuantitatif, Kualitatif, dan R\&D. Alfabeta. Supriyanti, A. (2020). PREDIKSI JUMLAH CALON PESERTA DIDIK BARU MENGGUNAKAN

METODE DOUBLE EXPONENTIAL SMOOTHING DARI BROWN ( Study Kasus : SD Islam Al-

Musyarrofah Jakarta ). Jurnal Lebesgue : Jurnal Ilmiah Pendidikan Matematika, Matematika Dan

Statistika, 1(1), 56-62. https://doi.org/10.46306/lb.v1i1

Susanto, A. (2013). Teori Belajar dan Pembelajaran di Sekolah Dasar. Kencana Prenada Media Group.

Susanto, H., Rinaldi, A., \& Novalia. (2015). Analisis Validitas Reabilitas Tingkat Kesukaran dan Daya

Beda pada Butir Soal Ujian Akhir Semester Ganjil Mata Pelajaran Matematika. Jurnal Al-Jabar, 6(2), 203-216.

Uno, H., \& Koni, S. (2016). Assessment Pembelajaran. Bumi Aksara.

Wijayanti, P. S. (2013). Pengaruh Pendekatan MEAs terhadap Kemampuan Pemecahan Masalah, Komunikasi Matematis, dan Kepercayaan Diri Siswa. Jurnal Pythagoras, 8(2), 181-192. 